\title{
Phytochemical Screening and Antibacterial Activity of Leaf Extracts of Gymnema sylvestre against Pathogenic Bacteria
}

\author{
N.Ramadass ${ }^{1}$, N. Subramanian ${ }^{1}$, R.Ponnulakshmi ${ }^{2}$, J.Selvaraj ${ }^{3}$, \\ ${ }^{1}$ PG and Research Dept. of Zoology, Arignar Anna Govt. Arts College), Cheyyar-604 407, Tamil Nadu, India \\ ${ }^{2}$ Dept. of Central Research Laboratory, Meenakshi Academy of Higher Education and Research, \\ (Deemed to be University) Chennai-600 078, India \\ ${ }^{3}$ Department of Biochemistry, Saveetha Dental College and Hospitals, Saveetha Institute of Medical and Technical Sciences, \\ Saveetha University, Chennai-600 077, India \\ *Corresponding author: nramadass1974@gmail.com
}

Available online at: www.isroset.org

Received: 30/Dec/2018, Accepted: 23/Jan/2019, Online: 28/Feb/2019

\begin{abstract}
The aim of our present study to investigate the phytochemical screening and antibacterial activity of Etholnolic and Chloroform leaf extracts of Gymnema sylvestre against some important pathogenic bacteria. The Ethonoloic and Choloroform leaf extracts of G.sylvestre showed significant antibacterial against some clinically important gram negative and gram positive bacteria such as Staphylococcus aureus (ATCC6538), Enterococcuc faecalis (ATCC 29212) and Escheria coli (ATCC8739), Salmonella enterica (ATCC 10798) respectively. The in-vitro antibacterial activity was performed by agar well diffusion method $(25,50,75$ and $100 \mu \mathrm{g} / \mathrm{ml})$. The maximum inhibition zone of ethonolic leaf extract was found in $100 \mu \mathrm{g} / \mathrm{ml}$ against gram negative bacteria such as Salmonella enterica $(26 \mathrm{~mm})$, Escheria coli $(24 \mathrm{~mm})$ and gram positive bacteria such as Enterocococcus faecalis $(26 \mathrm{~mm})$ and Staphylococcus aureus $(24 \mathrm{~mm})$. The maximum inhibition zone of chloroform leaf extracts found in $100 \mu \mathrm{g} / \mathrm{ml}(25,50,75$, and $100 \mu \mathrm{g} / \mathrm{ml})$ against gram negative bacteria such as Salmonella enterica $(24 \mathrm{~mm})$, Escheria coli $(24 \mathrm{~mm})$ and gram positive bacteria Enterocococcus faecalis $(23 \mathrm{~mm})$ and Staphylococcus aureus $(23 \mathrm{~mm})$. The phytochemical tests were carried out and showed that the antibacterial activity of plant Gymnema sylvestre leaves were due to presence of phytochemical compounds such as Alkaloids, Flvanoids, Glycosides, Reducing sugar, Tannins, Saponins, Polysaccharides and Phenols. The ethonolic and choloroform leaf extracts of Gymnema sylvestre showed maximum inhibition against Staphylococcus aureus, Enterocococcus faecalis, Salmonella enterica and Escheriacoli. The Ciprofloxacin was used as a positive control.
\end{abstract}

Keywords- Gymnema sylvestre, pathogenic microorganisms, antibacterial activity, bioactive components

\section{INTRODUCTION}

In the recent years, an increasing number of infectious agents are becoming more resistant to commercial antimicrobial components [1,2]. India is a paradise of medicinal plants and traditionally used many medicinal plant components are known as therapeutic properties from India $[3,4]$. The development of new antibacterial agent especially from the natural source is based on the pharmacological properties [5]. The Gymnema sylvestre is one of the most important medicinal plants that grow in tropical forests in Western India, Africa, Australia, South East Asia and India $[6,7]$. The plant has been reported to possess antimicrobial [8] and ethnoveterinary medicinal properties. The active ingredients are present in leaves and roots used in traditional medicine and available pharmaceutical products to treat various ailments like diabetes, asthuma and etc. [9]. In the Ayurvedic system of medicine, G. sylvestre is referred to as "mesarngi" and both the dried leaf and dried root are used therapeutically. The plant leaves are used in ayurvedic as antiviral, diuretic, antiallergic, hypoglycemic, hypolidemic, for the treatment of obesity and dental caries [10]. The antioxidant and antimicrobial activities of plant extracts have formed the basis of applications in pharmaceuticals, alternative medicines and natural therapy and growing demand for G. sylvestre leaves in pharmaceutical trade [11]. Gymnemic acid is the active ingredient of this plant, the extracted from leaves and used widely as an anti-diabetic [12] anti-sweetner [13] and antihypercholesterolemia [14]. It has also stomachic, diuretic and cough suppressant properties [15].

The several studies are reported that leaf extract of $G$. sylvestre has protective role against gram-positive bacteria such as $S$. mitis and $S$. mutans [16] and used to treating infectious diseases caused by Escherichia coli and 
Staphylococcus aureus [17] Bhuvaneshwari et.al., [18] demonstrated that the methonlic extracts of $G$. sylvestre were assessed for antimicrobial activity of leaves and root separately. The results revealed that the methanol extracts in acidic range have good activity towards all the pathogens. In a similar study carried out by Satdive et al., [8] the antimicrobial activity of ethanolic extracts of $G$. sylvestre against $B$. subtilis, B. pumilus, $S$. aureus and $P$. aeruginosa showed good antimicrobial activity. Hence, the present study was planned to find out the phytochemical properties and antimicrobial activities of ethanol and chloroform extracts of Gymnema sylvestre. The prepared extracts were screened for their antibacterial activity against clinically important pathogenic bacteria such as Staphylococcus aureus, Enterococcus enteric, Escheria coli and Salmonella enterica. The presence of phytochemical components and antibacterial properties can lead to detect new sources of antibacterial agents.

\section{MATERIALS AND METHODS}

\section{Collection of plant}

The leaves of Gymnema sylvestre were collected from Cheyyar, Thiruvannamalai District, Tamil Nadu and India. The species was identified and authenticated by the Department of Botany, Arignar Anna Government Arts College, Cheyyar, Thiruvannamalai District,Tamil Nadu.

\section{Microorganisms used}

Gram positive bacteria such as Staphylococcus

aureus (ATCC6538), Enterococcus enterica (ATCC 2912)

and Gram negative organism such as Escheria coli

(ATCC8739), Salmonella enterica (ATCC 10798) were used for antibacterial study.

\section{Preparation of plant extracts}

The leaves of Gymnema sylvestre were cleaned and dried in shade under dark room, then cut into small pieces and coarsely powdered by mixer. The course powder was used for extraction with various solvents. In $1 \mathrm{~kg}$ of dried leaf powder added 2.5 liters of solvents (water, ethanol, and chloroform) was taken in individual aspirator bottle, were used and the mixtures were shaken occasionally in Orbital shaker for 72 hours. Then the extract was filtered. This procedure was repeated three times and all extracts were decanted and pooled. The extracts were filtered before drying using Whatmann filter paper no.1 on a Buchner funnel and the solvent was removed by vacuum distillation in a rotary evaporator at $40^{\circ} \mathrm{C}$, the extracts were placed in pre-weighed flasks before drying. Finally the aqueous, ethanol and chloroform extracts of Gymnema sylvestre leaves were used for the preliminary phytochemical screening and antibacterial study.

\section{Phytochemical Screening}

Phytochemical screening in the Gymnema sylvestre leaf extract using different solvent systems (aqueous, ethanol and chloroform) were carried out as per the standard method of Dey and Raman [19].

\section{Antibacterial Activity}

Antibacterial activity of Aqueous, Ethanol and Chloroform extracts of Gymnema sylvestre were done by the method of Gillespe et al., [20,21] by using disc diffusion method with both Gram negative and positive bacteria.

\section{Procedure}

Aqueous, Ethanol and Chloroform extracts $(10 \%$ and $50 \%$ ) solution were prepared by dissolving 1 and $5 \mathrm{~g}$ in 10 $\mathrm{ml}$ each of distilled water. $10 \mathrm{ml}$ each of the prepared concentrations were pipette into sterile test tubes. Bacterial aliquots of the test organisms were made by scooping 2 colonies each of a 24 hours growth of the bacteria into $4 \mathrm{ml}$ of sterile distilled water. $0.2 \mathrm{ml}$ of each of the aliquots containing approximately $5 \times 104$ bacterial cells or colony forming units was transferred into both of the extract concentrations and allowed to stand for an hour for reaction to take place between the extracts and the bacterial organisms. The mixtures were then inoculated on separate nutrient agar plates and incubated at $37^{\circ} \mathrm{C}$ for 24 hours. Ethanolic and aqueous extracts of the leaves at 10 and 50\% concentration of both chloroform and aqueous extracts of leaves had inhibitory effect, hence the same concentrations were chosen as the working concentration. Results are expressed in area of inhibition zone in $\mathrm{mm}$.

\section{RESULTS AND DISCUSSION}

The phytochemical analysis of Gymnema sylvestre leaf extract using Aqueous, Ethanolic and Chloroform were showed in Table 1. From the observation of phytochemical analysis, reducing sugar was found in Gymnema sylvestre in all three solvents. The Ethanol and Chloroform leaf extracts of Gymnema sylvestre showed the presence of alkaloids, flavanoids, glycosides, tannins, saponins, polysaccharide, phenols and absence of terpenoids, phytosterols but which were present in aqueous leaf extract. Aqueous extracts of Gymnema sylvestre have flavanoids, glycosides, reducing sugar, polysaccharides, phtoseterois and phenols. The presences of above bio active components are responsible for broad pharmacological profile, including antibacterial activity [22].

The Aqueous, Ethanol and Chloroform leaf extracts were tested using agar plate disc diffusion method against gram positive bacteria such as Staphylococcus aureus (ATCC6538), Enterococcus enteric (ATCC 2912) and gram negative bacteria such as Escheria coli (ATCC8739), Salmonella enterica (ATCC 10798. Table 2 and 3 showed antibacterial activity of ethanol leaf extract of Gymnema sylvestre found maximum inhibitory zone $(26 \mathrm{~mm}$ in 75 and $100 \mu \mathrm{g} / \mathrm{ml}$ ) against gram positive bacteria Enterococcus faecalis followed by $24 \mathrm{~mm}, 25 \mathrm{~mm}$ in 25 and $50 \mu \mathrm{g} / \mathrm{ml}$ 
respectively. The Staphylococcus aureus, maximum zone of inhibition $(24 \mathrm{~mm}$ in 75 and $100 \mu \mathrm{g} / \mathrm{ml})$ and followed by $21 \mathrm{~mm}, 23 \mathrm{~mm}$ in 25 and $50 \mu \mathrm{g} / \mathrm{ml}$ respectively (Figure 1). The antibacterial activity of Gymnema sylvestre found maximum inhibition zone $(26 \mathrm{~mm})$ against gram negative Salmonella enterica bacteria followed by $24 \mathrm{~mm}, 25 \mathrm{~mm}$ in 25 and $50 \mu \mathrm{g} / \mathrm{ml}$ and Escherichia coli maximum zone of inhibition $(24 \mathrm{~mm}$ in $100 \mu \mathrm{g} / \mathrm{ml})$ and followed by $19 \mathrm{~mm}$ , $21 \mathrm{~mm}$ and $23 \mathrm{~mm}$ in 25,50 and $75 \mu \mathrm{g} / \mathrm{ml}$ respectively (Table 4,5 and Figure 2).

The Choloroform leaf extract of $G$.sylvestre were observed the maximum inhibition zone $(23 \mathrm{~mm}$ in 75 and $100 \mu \mathrm{g} / \mathrm{ml}$ ) against gram positive bacteria Staphylococcus aureus and Enterococcus faecalis followed by $23 \mathrm{~mm}, 23 \mathrm{~mm}$ in 75 and $100 \mu \mathrm{g} / \mathrm{ml}$ respectively (Figure 3). The maximum inhibition zone of Salmonella enterica and Escheria coli were $24 \mathrm{~mm}$ in 75 and $100 \mu \mathrm{g} / \mathrm{ml}$ respectively (Table 4, 5 and Figure 4).

This experimental studies explained about the presence of bioactive compounds in the Gymnema sylvestre leaf extract from different solvent extracts such as flavanoids, glycosides, reducing sugar, polysaccharides, phytosterols and phenols source of which compound have been associated to antibacterial activity against pathogens [6]. The G. sylvestre leaf extract were used in this study of different extracts and their antibacterial efficacy depend on the extractive solvent [23]. The ethanol leaf extracts of $G$. sylvestre more potential activity than the chloroform leaf extrat. The phytochemical analysis showed the presence of various bioactive compounds like alkaloids, flavanoids, glycosides, tannins, saponins, polysaccharides and phenols.

\section{CONCLUSION}

The present studies were revealed that the ethanol and chloroform leaf extract of Gymnema sylvestre showed significant activity against gram positive bacteria such as Staphylococcus aureus and Enterococcus faecalis and gram negative bacteria Escheria coli and Enterococcus faecalis. The ethanol leaf extracts of $G$ sylvestre more potential activity than the chloroform leaf extract. The phytochemical analysis showed the presence of various bioactive compounds like alkaloids, flavanoids, glycosides, tannins, saponins, polysaccharides and phenols. This studies may further leads to the formulation of a new drug having the active compound.

Table 1: Phytochemical screenings of leaf extract $G$. sylvestre in different solvents

\begin{tabular}{|l|c|c|c|}
\hline Tests & Plant extracts & Plant extracts & Plant extracts \\
\hline & Aqueous & Ethanol & Chloroform \\
\hline Alkaloids & - & + & + \\
\hline Flavanoids & + & + & + \\
\hline Glycosides & + & + & + \\
\hline Reducing Sugar & + & + & + \\
\hline Tannins & & + & + \\
\hline Saponins & - & + & + \\
\hline Terpenoids & - & - & - \\
\hline Polysaccharides & + & + & + \\
\hline Phytosterols & + & - & - \\
\hline Phenols & + & + & + \\
\hline
\end{tabular}

+: Present; $\quad$ - : Absent

Table: 2. Antibacterial activity of ethanolic extract of Gymnena sylvestre in Gram positive bacteria

\begin{tabular}{|c|l|c|c|c|c|c|c|}
\hline S.No & \multicolumn{1}{|c|}{$\begin{array}{c}\text { Name of the Micro } \\
\text { organism }\end{array}$} & $\begin{array}{c}\text { Reference Drug (Positive } \\
\text { control) }\end{array}$ & $\mathbf{2 5} \boldsymbol{\mu g} / \mathbf{m l}$ & $\begin{array}{c}\mathbf{5 0} \\
\boldsymbol{\mu g} / \mathbf{m l}\end{array}$ & $\begin{array}{c}\mathbf{7 5} \\
\boldsymbol{\mu g} / \mathbf{m l}\end{array}$ & $\begin{array}{c}\mathbf{1 0 0} \\
\boldsymbol{\mu g} / \mathbf{m l}\end{array}$ & $\begin{array}{c}\text { Negative } \\
\text { Control }\end{array}$ \\
\hline 1 & Staphylococcus aureus & $26 \mathrm{~mm}$ & $21 \mathrm{~mm}$ & $23 \mathrm{~mm}$ & $24 \mathrm{~mm}$ & $24 \mathrm{~mm}$ & - \\
\hline 2 & $\begin{array}{l}\text { Enterococcus } \\
\text { faecalis }\end{array}$ & $28 \mathrm{~mm}$ & $24 \mathrm{~mm}$ & $25 \mathrm{~mm}$ & $26 \mathrm{~mm}$ & $26 \mathrm{~mm}$ & - \\
\hline
\end{tabular}

Table 3: Antibacterial activity of ethanolic extract of Gymnema sylvestre in Gram negative bacteria

\begin{tabular}{|c|l|c|c|c|c|c|c|}
\hline S.No & $\begin{array}{c}\text { Name of the Micro } \\
\text { organism }\end{array}$ & $\begin{array}{c}\text { Reference Drug (Positive } \\
\text { control) }\end{array}$ & $\mathbf{2 5 \mu g / m l}$ & $\begin{array}{c}\mathbf{5 0} \\
\boldsymbol{\mu g} / \mathbf{m l}\end{array}$ & $\begin{array}{c}\mathbf{7 5} \\
\boldsymbol{\mu g} / \mathbf{m l}\end{array}$ & $\begin{array}{c}\mathbf{1 0 0} \\
\boldsymbol{\mu g} / \mathbf{m l}\end{array}$ & $\begin{array}{c}\text { Negative } \\
\mathbf{C o n t r o l}\end{array}$ \\
\hline 1 & Escherichia coli & $26 \mathrm{~mm}$ & $19 \mathrm{~mm}$ & $21 \mathrm{~mm}$ & $23 \mathrm{~mm}$ & $24 \mathrm{~mm}$ & - \\
\hline 2 & Salmonella enterica & $28 \mathrm{~mm}$ & $24 \mathrm{~mm}$ & $25 \mathrm{~mm}$ & $26 \mathrm{~mm}$ & $26 \mathrm{~mm}$ & \\
\hline
\end{tabular}




\section{Results for antibacterial study}

Staphylococcus aureus

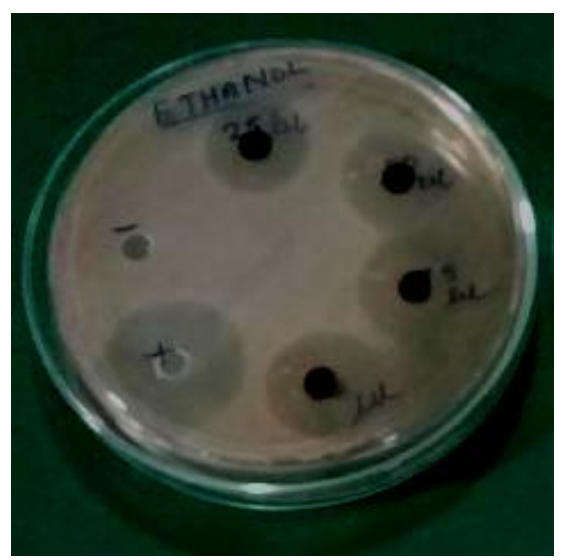

Figure 1. Antibacterial activity of ethanolic extract of Gymnema sylvestre in Gram positive bacteria
Enterococcus faecalis

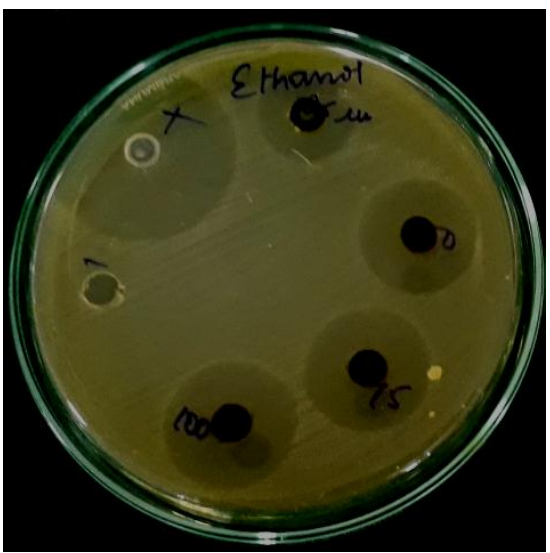

Salmonella enterica

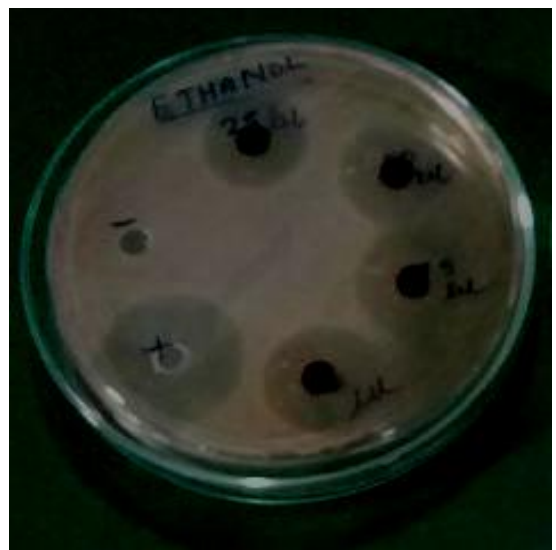

Figure 2. Antibacterial activity of ethanolic extract of Gymnema sylvestre in Gram negative bacteria

Table 4: Antibacterial activity of chloroform extract of Gymnema sylvestre in Gram positive bacteria

\begin{tabular}{|c|l|c|c|c|c|c|c|}
\hline S.No & $\begin{array}{c}\text { Name of the Micro } \\
\text { organism }\end{array}$ & $\begin{array}{c}\text { Reference Drug } \\
\text { (Positive control) }\end{array}$ & $\mathbf{2 5 \mu g} / \mathbf{m l}$ & $\mathbf{5 0} \boldsymbol{\mu g} / \mathbf{m l}$ & $\mathbf{7 5} \boldsymbol{\mu g} / \mathbf{m l}$ & $\mathbf{1 0 0} \boldsymbol{\mu g} / \mathbf{m l}$ & $\begin{array}{c}\text { Negative } \\
\text { Control }\end{array}$ \\
\hline 1 & Staphylococcus aureus & $24 \mathrm{~mm}$ & $18 \mathrm{~mm}$ & $20 \mathrm{~mm}$ & $23 \mathrm{~mm}$ & $23 \mathrm{~mm}$ & - \\
\hline 2 & Enterococcus faecalis & $24 \mathrm{~mm}$ & $19 \mathrm{~mm}$ & $22 \mathrm{~mm}$ & $23 \mathrm{~mm}$ & $23 \mathrm{~mm}$ & - \\
\hline
\end{tabular}

Table 5: Antibacterial activity of chloroform extract of Gymnema sylvestre in Gram negative bacteria

\begin{tabular}{|c|l|c|c|c|c|c|c|}
\hline S.No & $\begin{array}{c}\text { Name of the Micro } \\
\text { organism }\end{array}$ & $\begin{array}{c}\text { Reference Drug } \\
\text { (Positive control) }\end{array}$ & $\mathbf{2 5} \boldsymbol{\mu g} / \mathbf{m l}$ & $\mathbf{5 0} \boldsymbol{\mu g} / \mathbf{m l}$ & $\mathbf{7 5} \boldsymbol{\mu g} / \mathbf{m l}$ & $\mathbf{1 0 0} \boldsymbol{\mu g} / \mathbf{m l}$ & $\begin{array}{c}\text { Negative } \\
\text { Control }\end{array}$ \\
\hline 1 & Escherichia coli & $30 \mathrm{~mm}$ & $20 \mathrm{~mm}$ & $22 \mathrm{~mm}$ & $24 \mathrm{~mm}$ & $24 \mathrm{~mm}$ & - \\
\hline 2 & Salmonella enterica & $28 \mathrm{~mm}$ & $19 \mathrm{~mm}$ & $23 \mathrm{~mm}$ & $24 \mathrm{~mm}$ & $24 \mathrm{~mm}$ & - \\
\hline
\end{tabular}

Reference Drug (Positive Control): Ciprofloxacin; Negative Control: DMSO 

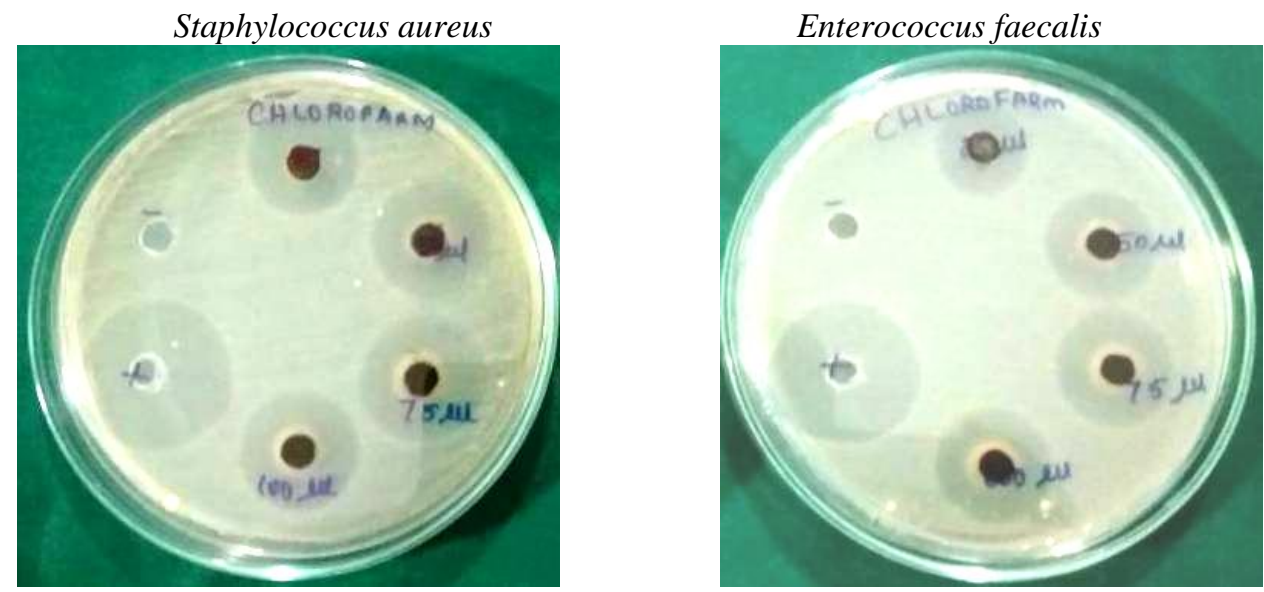

Figure 3. Antibacterial activity of chloroform extract of Gymnema sylvestre in Gram positive bacteria
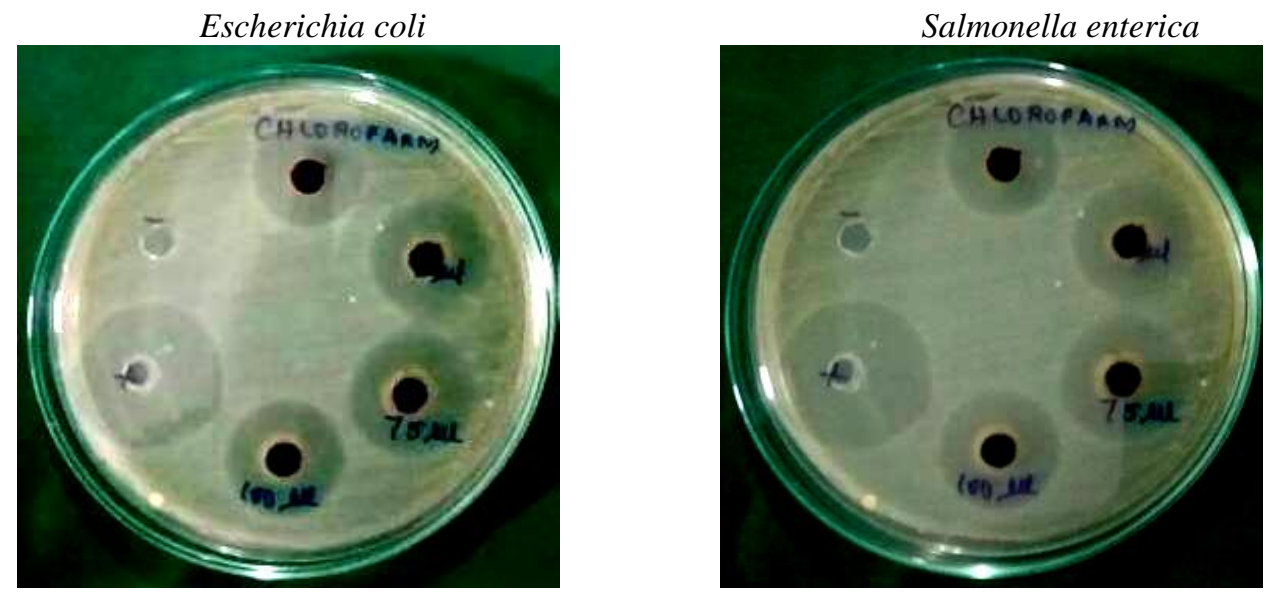

Figure 4. Antibacterial activity of chloroform extract of Gymnema sylvestre in Gram negative bacteria

\section{REFERENCES}

[1] R.B. Pratibha and Pratibha Singh, "Antimicrobial activity of Gymnemic acid on pathogens- Gymnema sylvestre", International Journal of Current Microbiology and Applied Sciences, Vol.3, No. 5, pp.40-45, 2014.

[2] R. E. Hancock, A. Nijink, D. J. Philpott, "Modulating immunity as a therapy for bacterial Infections", Nat. Rev. Microbiol., Vol.10, pp. 243-254, 2012.

[3] J. Bruenton, "Pharamacognosy, Phytochemistry, Medicinal plants", Lavoilver 265-380,1995,

[4] M. Murugan, V.R. Mohan and V. Thamodharan, "Phytochemical screening and antibacterial activity of Gymnema sylvestre (Retz) R. Br ex. Schultes and Morinda pubescens J.E. Smith var. pubescens", Journal of Applied Pharmaceutical Sciences, Vol.2, Issue,2, pp.73-76, 2012.

[5] J. Kader, H. M. Noor, S.M. Radzi and N.A.A. Wahab, “ Pharmacodynamic Properties of Extracts from Different Parts of Euphorbia hirta on Staphylococcus epidermidis and Shigella sonnei", Asian Journal of Biochemicial and Pharmaceutical Research, Vol,3, Issue.4, pp.154-164, 2013.

[6] Sudhanshu, M. Sandhya, Nidhi Rao, Mohit Soni, and Ecta Menghassi, "Phytochemical Potentials of Gymnema
Sylvestre, Adiantum Lunulatum, Bryonia Laciniosa", Asian Journal of Biochemical and Pharmaceutical Research, Vol. 2, Issue.3, pp.8-13, 2012.

[7] W. Stocklin, "Chemistry and physiological properties of gymnemic acid, the antisaccharine principle of the leaves of Gymnema sylvestre", Journal of Agricultural and Food Chemistry, Vol .17, Issue. 4, pp.704-708, 1969.

[8] R. K. Sative, P. Abhilash, D.D. Fulzele, "Antimicrobial activity of Gymnema sylvestre leaf extract" Fitoterapia, No.74, pp.699-701, 2003.

[9] V. K. Sing P. Dwivedi, B. R. Chaudhary, B. R. Sing, "Immunomodulatory Effect of $\quad R$. Gymnema sylvestre (Br.) Leaf Extract: An In Vitro Study in Rat Model", PLos ONE, Vol.10, Issue.10, journal pone. 01396, 2015.

[10] C. K. Kokate, A. P. Purohit, S. B. Gokhale, "Pharmocognasy", Nirali Prakasan, $36^{\text {th }}$ Edition, Pune, pp.252, 2006.

[11] P. Muthukumaran, P. Shunmuganathan and C. Malathi, "Antioxidative and Antimicrobial Study of Aerva Lanata", Asian Journal of Biochemical and Pharmaceutical Research, Vol. 1, Issue 2, pp.265-271, 2011.

[12] K. R. Shanmugasundaram , C. Panneerselvam , P. Samudram, E. R. Shanmugasundaram, "Enzyme changes and glucose utilisation in diabetic rabbits: the effect of 
Gymnema sylvestre, R.Br", Journal of. Ethnopharmacol., No.7, pp.205-234, 1983.

[13] Y. Kurihara, "Characteristics of antisweet substances, sweet proteins and sweetness inducing protein", Crit. Rev. Food Sci. Nutr., No.32, pp.231-252, 1992.

[14] A. Bishayee and M. Chatterjee, " Hypolipemic and antiatherosclerotic effects of oral Gymnema sylvestre R.Br. leaf extract in albino rats fed on a high fat diet", Phytotheraphy, Res.8, pp.118-120, 1994.

[15] L. D. Kapoor, "CRC Handbook of Ayurvedic medicinal plants", Boca Raton: CRC Press; pp.200-201, 1990.

[16] T. Pragya, B. N. Mishra, and S. Neelam, Sangwan, "Phytochemical and Pharmacological Properties of Gymnema sylvestre: An Important Medicinal Plant" Hindwai Publishing Corporation, Bio. Med. Res. Inter., Article ID 830285 pp.1-18, 2014.

[17] G. K. Kishore Naidu K. Chandra Sekar Naidu and B. Sujatha, "In Vitro Antibacterial Activity and Phytochemical Analysis of Leaves of Gymnema sylvestre Retz.R.Br", International Journal of Pharm. Tech. Research.,Vol.3, Issue.5, pp.1315-1320, 2013.

[18] C. Bhuvaneswari, R. Kiranmaycc and G. Archana, "Phytochemical analysis of Gymnema sylvestre and evaluation of its antimicrobial activity", Natural Product Research, Vol.6, Issue.27, pp.583-587, 2013.

[19] Dey B and Sita Raman M.V, "Laboratory Manual of organic Chemistry". S.Viswanathan publication, Madras, 1957.

[20] Gillespie, S.H, "Evolution of drug resistance in Mycobacterium tuberculosis: clinical and molecular perspective", Antimicrobial Agents and Chemotherapy, No.46, pp.267-274, 2002.

[21] Indian Pharmacopoeia, Govt. of India, The Controller of Publications, Delhi, 1996.

[22] A. Wajaht Shah and Sofi Mubashir, "Phytochemical Screening, Antioxidant and Antimicrobial Activities of Myricaria Germanica" Asian Journal of Biochemical and Pharmaceutical Research, Vol.3, Issue. 4, pp.135-139, 2013.

[23] B. Bader and A. Saeed, "Evaluation of Antimicrobial Action of Selected Sudanese Folk Medicinal Plants “, Asian Journal of Biochemical and Pharmaceutical Research, Vol. 6, Issue. 2 pp.157-163, 2016. 